\title{
A NEW LANGUAGE POLICY FOR INDONESIA
}

\author{
EKO SAPUTRA', ANDRI SAPUTRA² \\ University of Prof. Dr. Hazairin, S.H.' \\ IAIN Bengkulu ${ }^{2}$ \\ Ekosaputra17022019@gmail.com', andrisaputra@iainbengkulu.ac.id ${ }^{2}$
}

DOI : http://dx.doi.org/10.29300/ling.v6i1.2969

Received April 2020

Accepted: May 2020

Published: July 2020

\begin{abstract}
Indonesia is the house of multicultural ethnic groups with more than 700 individual vernacular languages. This diversity puts Indonesia into both strategic and a vulnerable condition. It is strategic because the culture-rich Indonesia can commodify the diversity for the benefits of the people, however, it is also vulnerable as it can pose serious threats to the existence of the nation. For several decades, Indonesia has given attention to the language policy. Yet, the implementation still needs appropriate modification for the improvement. Objective of the paper: This paper is written on the purpose of giving a new form of language policy to be implemented in Indonesia. Theoretical Framework: A scheme of language policy is proposed for educational setting in Indonesia. Justification: Some arguments are also provided to provide a strong justification for the necessity of implementation of the policy. Conclusion: 1 . It is imperative to have a language policy that can promote unity and prevent any potential separatism, provide a sense of belonging to the nations and ethnic culture in terms of nationalism, and open access to knowledge enhancement and the global world. 2. It is also important to have qualified and committing teachers to the implementation of language policy. If both points are present, the benefits of language policy can obviously be obtained.
\end{abstract}

Keywords: Language policy, vernacular, lingua franca

\section{INTRODUCTION}

Language is one of the precious assets that human beings have. Indonesia is the place where this type of asset is abundant and various. At least, there are more than 700 individual languages used as vernaculars that can be counted in this country (Gordon, 2014). This intangible asset can be either a strength or weakness that Indonesia has. If perfectly managed, this asset can be something that Indonesian should be proud of, diversity. Otherwise, if poorly managed and not devoting serious attention, it can be a serious threat that can not only harm but also destroy the nation.

Since successfully gaining its independence in 1945, Indonesia has tried its best to deal with the language policy issue. Suryanto, Suparno and Herawati (2019) argue that Indonesia has been having a periodically renewed language political concept that is put into a practice. In other words, language policy has been consistently created and implemented based on the situation and condition at respective moments. However, problems are still found there and can still be a potential threat. It ranges from the inevitable decline of vernaculars (Musgrave, 2014) 
and an inconsistent act of language teachers to the demand of language policy mandated by the government. While the government asks them to use the communicative approach for English teaching, the teachers still focus on teaching explicit grammar instructions (Murniati \& Riyandari, 2016). What is expected from the English language policy is not yet achieved.

What Indonesia has seriously prioritized is to make all of the citizens able to utilize English as a means of communication. The ratification of the Association of South East Asian Nations (ASEAN) community in 2015, has opened a new level of economic interaction among its members. Since English is the ASEAN de facto lingua franca (Kirkpatrick, 2007), mastering it to the level of being able to communicate is undeniably essential. Then, it will only happen if the teachers can implement the communicative approach that the government demands. Otherwise, Indonesia will not be able to gain much from the ratification.

This paper tries to offer a theoretical perspective of language policy that can address the previously mentioned issues that Indonesia encounters. I divide them into three segments. The first one, I would start with the explanation of several current issues related to the language policy in Indonesia. After that, I would propose a language policy plan that can address the issues mentioned before. Lastly, I would provide some justifications as a means to support the implementation of the policy.

\section{LANGUAGE POLICY \& EDUCATION}

Some scholars have proposed definitions of language policy. According to Rubin \& Jernudd (1971) Language Policy is "decision making about language" (p. 2). This definition is very broad and not much information can be gained especially in terms of language policy. Weinstein (1980) defines language policy as "A government authorized long term sustained and conscious effort to alter a language itself or to change a language functions in a society to solve communication problem" (p. 3). For this definition, a clearer picture regarding language policy is at least provided than the previous one of which three important aspects of information can be noted. First, it is the domain of government that makes and runs a language policy. Second, language policy is made as a response to solve the communication problems that appear in society. Third, this requires a quite long time before we could see the impact. Another one is from Ager (2001) who defines Language policy as "official planning, carried out by those in political authority" (p. 5). Usually, regardless of any political system a country has, people who are elected and serve in governmental positions such as presidents, governors, mayors are also at the stage of political interest. Acting as the government, those people who sit in power are chosen by their voters because they could best represent the interest of their constituents. The policy that they make usually come out from the act of serving their voters in other words as the product of political interest. Therefore, the policy that they create will also Linguists: Journal of Linguistics and Language Teaching Vol. 6, No. 1, July 2020 
be likely to carry the interest of the group that they represent. Then, it is acceptable to say "language policy is not neutral" (Shohamy, 2006, p. 78).

In terms of education, it is an integral part of language policy. Although Shohamy (2006) argues that language policy in education is the form of imposition and manipulation of language policy set by the authority to turn ideology into practicality, it is also the place where government officers either apply or design the policy. It is the scholars whom to consult when designing a language policy or running a language policy. For example, Jaffe (2011) claims that the revival of Corsian French language cannot be separated from the role of language policy in education. For almost 30 Corsian French language had been absent from school, but after it was mandated to be taught in schools, the number of bilingual students increased. This phenomenon can be considered as an implication of how language education policy plays a significant role in reviving a language back to life even with the one that is almost (if not) dead.

\section{LANGUAGE POLICY, EDUCATION, AND VULNERABLE THREAT OF DIVERSITY IN INDONESIA}

\section{Government Policy About Language}

Indonesia, a country with a population of over 250 million people is one of the most diverse populating countries in the world. There, at least, are 719 languages (Gordon, 2014), considered as vernaculars, widely used by multi-ethnic groups spread among 17.504 islands (Statistik, 2013). Based on its constitution in 1945, this country declares that Indonesian language or 'Bahasa' as the national language (See Indonesia, 2002). As a consequence, Bahasa is widely used as the medium of communication in government domains such as official ceremonies and documents. On the other hand, the constitution also acknowledges the status of vernacular languages by respecting and preserving it as part of Indonesian cultures.

This declaration also gives a serial implicatures to education policy. The government of Indonesia even articulates its language policy in the Constitution No. 20 National Education System 2003. It is stated that 1) Indonesian language (Bahasa) is used as the medium of instruction; 2) Vernaculars can be used as the medium of instruction in the early stage of education when needed for the specific knowledge transfer ; 3) Foreign language(s) can be used as the medium of instruction in more specific circumstances such as for supporting the learners' foreign language skills (Nasional, 2003). Each of the points is created for several possible reasons.

For the first point, it can be inferred that the final goal of education in Indonesia in terms of language skills is to get the people to be skillful in acquiring and using Bahasa for formal settings as Lopes (1998) argues that education is the best alternative place for language 
promotion. As most Indonesians start their life by studying in educational institutions, all of them are expected to be Bahasa competent speakers when they have finished their educations. The second one, a classical and still relevant reason for giving space to vernaculars in the education domain is because Bahasa is not Indonesians' first language (Nababan, 1991). It is imperative to nationalize Indonesian people by promoting one national language which is Bahasa in their educational domain. However, since the first language of Indonesian people are vernaculars, special but limited space is allocated for them within the curriculum. Yet, the use of vernaculars is only on the early stage which is year one and two of elementary education (see Nasional, 2003, p. 27). Third, the government also promotes foreign language subject in education and serve it as the medium of instruction at specific circumstances because it is an important asset in this globalization era. English as a foreign language has been one of the compulsory subjects in the national examination for Primary (Junior High school) and secondary level.

\section{Current Educational Issues}

However, on the practical level, the education situation in Indonesia does not run as ideal as what is planned. The result of the study from the Program of International Students Assessment (PISA) showed that Indonesian people's literacy is still low. Among 65 countries with low literacy levels, Indonesia is in the 10 lowest position (see Kebudayaan, 2012). There can be many factors influencing this unsatisfying result. One among the strongest ones is that there is a link between low level of students' achievements and teachers' qualification (Akiba, LeTendre, and Scribner, 2007). Learners gain knowledge and skill from the teachers. If the teachers in charge of teaching the students do not have the quality that is required, the knowledge and skills taught might not be transferred well to the students.

Furthermore, sometimes the change in the structure of the ministry of education also gives inconsistent acts towards the language policy in education. Under the new national education curriculum 2013, the government surprisingly abolishes English subject in the elementary school level. At one level government might think that elementary level shall be prioritized for mastering Bahasa, but on the other hand, it can obviously screw the curriculum structure for English teaching. English materials are knowingly designed as related from elementary to senior high school level.

In responding to these two problems, the government has made a serious attempt. For example, the enactment of The Decree of Minister of National Education Republic of Indonesia No. 16/2007 on Standards of Teachers' Academic Qualification and Competence and Chapter 29 of The Government Law of Republic Indonesia No. 20/2005 On National Standard on Education (Departemen Pendidikan Nasional, 2007). As a result, teachers intending to teach at 
elementary to senior high school level are required to have at least a bachelor degree certificate or those with a similar level (Hendarti, 2012). Therefore, if a person wants to be an elementary school teacher, they must have at least sufficient-teaching qualifications in both practical and theoretical levels. This can be pursued by studying in the formal education.

However, for the abolition of the English subject in elementary school, there seems to be not enough attention. If the students are taught English when they enter junior high school, then a series of curriculum modification has to be done. If the basic English used to be taught at the elementary one, now it shall be started at the level of junior high school.

\section{Separatism Issues}

Being one of the most diverse ethnic country in the world, Indonesia is very prone to the emergence of separatist movements. At least, there are three major separatist movements recorded in the Indonesian history. Some of them are still actively consolidating power in the form of an underground movement. First is Indonesia's' free Aceh Movement (GAM) led by Teungku Daud Beureueh (1899-1987). He declared to fight against Indonesia's legitimate government demanding the separation of Aceh from Indonesia and insisting on the new form of Acehnese Islamic State on 4 December 1976 (Al Qurtuby, 2015). Indonesian Government had as at least to deploy two times of emergency status in 1980 (Rüland \& Manea, 2013) and 2005 (Qurtuby, 2015). The bloody 30-year-old conflict finally resolved through Helsinki peace agreement in 2005 in which Aceh is granted as special autonomy to incorporate Islamic Sharia Law into its province under the Indonesian republic. However, no one can give a warranty that the agreement has completely exterminated the movement.

Second, the separatist movement of the 'Free Papua Movement' ('Organisasi Papua Merdeka-OPM). Formed in 1965 with the key leaders Seth Rumkorem a former officer of the Indonesian army and Jacob Prai, it began to spread terrors to locals and souldiers and police and demand the freedom of West Papua from Indonesia (Webb-Gannon, 2014). Elicited by the feeling of unfair treatment from the central government of Indonesia, this movement demands compensation for environmental damages, a halt to logging and independence for the region (McDonald and Lemko, 2001). Although, Papua has been given a special autonomy and budget allocated for enhancing its area, the issue of OPM is never really solved. Once in a while, a case of gun firing by unknown people believed as the underground followers of this movement cause death casualties of Indonesian military personnel or locals that they perceive as the enemy.

Third, the former totalitarian regime of president Suharto who had ruled as Indonesia's president for almost 32 years before forced to step down by massive demonstration in 1998 . 
$\mathrm{He}$ is believed to be responsible for the formation of separatism movement in Maluku 'Republic of South Maluku' (Republik Maluku Selatan-RMS). His policy that transmigrated people from the over-crowded population in Java island to Maluku had created not only ethnic but also religious tension. Maluku used to be an area with predominantly populated Christians drastically changed to 51\% Muslims and 49\% Christians (McDonald \& Lemco, 2001). His policy had made the number of Muslim population outweigh the number of Christian population. Ethnic conflict broke and at least 5000 people from both Muslims and Christian groups were killed (Goss, 2000).

All of the examples above are only some of several long stories of separatist movements in Indonesia. Even though the conflicts were not primarily triggered by language but it is fair enough to conclude that, to a certain degree, diversity brings to the severe consequences. Citizen will always be the disadvantaged party. A new policy that can solve this problem is very needed. A policy that is not only able to recover the situation but also preemptive any possibility of a problem in the future. Therefore, I propose a language policy or a medium for Indonesian people to be able not only to communicate and understand each other better but also to enhance their educational sector as well.

\section{POLICY MODEL}

\section{Current Application of Language policy in Education Domain in Indonesia}

In the current condition, Indonesian children will start their formal education from elementary school. They will normally spend 6 years of studying at this level. Once they enter their first year of studying in the classroom they will have to master Bahasa as the national language and Bahasa will always be used as the medium of instruction in the education domain afterward. Since not all children use Bahasa as their daily communication medium and also their mother tongue might be different from Bahasa or completely different from Bahasa, it is important to serve the early learners with their mother tongue or vernaculars at this level. Logically, at least it will ease them in conveying the teaching and learning process as well as the materials. However, these services are only given for the first two years (Nasional, 2003, p. 27). After they entered grade three to six, the students will completely be given Bahasa as their language of instruction.

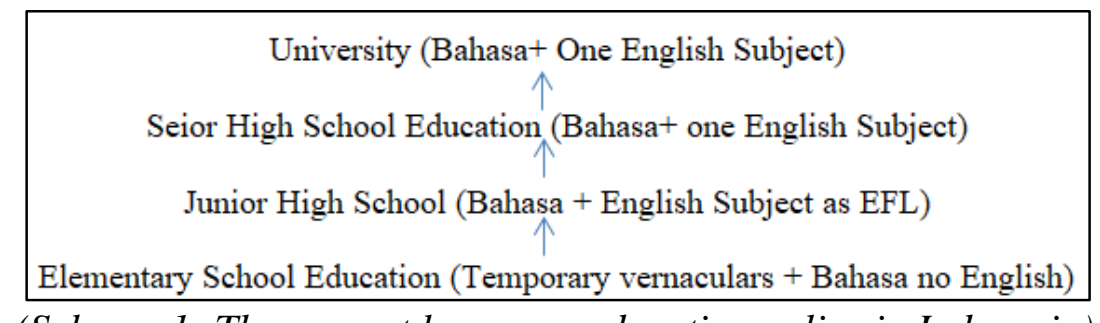

(Schema 1: The current language education policy in Indonesia) 
Once they entered Junior high school, they will be introduced to English as a foreign language. At this level, the government of Indonesia firmly requires the students to at least know English at the level of theory. Many of the teaching materials and instructions are not designed for communicative purposes. Before 2020, there was a national examination for elementary school, junior high school, and senior high school students. English together with Bahasa was once one of the compulsory national examination subjects for the junior high school students to pass to continue to senior high school. If they failed in either English or Bahasa in the national Examination, they would fail to continue to the senior high school level. They either needed to wait for the next year's examination or took a special program designed by the government for people who want to get a formal education certificate called paket. Both of the options were not preferential since they would not be able to apply to good quality senior high school.

This process will be similar when the students enter Senior High School and University. They have to pass English in the national Examination to graduate from Senior High School. In addition, once they want to enter a university there will be Selection Process in the form of a test. That test also has English subjects to pass no matter what major they want to pursue. If they want to take Bahasa Major in which they will not study English they will still need to pass the English National Selection Examination for University.

However, the national examination is no longer used as formal education measurement in Indonesia. It is replaced by "minimum competency assessment and character surveys" (CNA, 2020). Unfortunately, it does not mean that the students would be free from their responsibility of mastering the English language and Bahasa. When they have become university students, they will have to take TOEFL or test English as a Foreign Language in order to graduate with the minimum standard. If they can successfully enter a reputable university, English competency will be needed when working with course works where most of them will be conducted in English or at least require English reading ability to read English learning materials. Therefore, a language policy to address this issue is really crucial for the students to have. Otherwise, the will seriously encounter a language barrier problem in enhancing their knowledge and skills. Therefore, a good language modified language policy is needed.

\section{The Proposed Model of New Language Education Policy}

In general, one might find that the policy I propose is not different from what currently has been applied in Indonesia. However, if he wants to pay more attention to the details, he will find that the policy has three distinguished main aspects. The first one, this policy provides 
language adjustment when the students are introduced to a new language to acquire. The second one, there is a requirement for both the teacher and students to use the target languages both spoken and written. Third, languages are not only understood as a medium of communication but also more specifically as a medium of acquiring knowledge.

Starting from the first one, the elementary school. Here, the students will be given the flexibility to speak either their vernaculars or Bahasa. The teachers will be those who are qualified with both the skill of the vernacular and Bahasa. To support the learning process the students will also be provided bilingual books that are written in Bahasa and Vernacular language depending on the student needs. In this level, vernaculars are actively used to accompany the process of Bahasa acquisition. Unlike the current policy, this proposed policy will incorporate vernacular until the students graduate the elementary school.

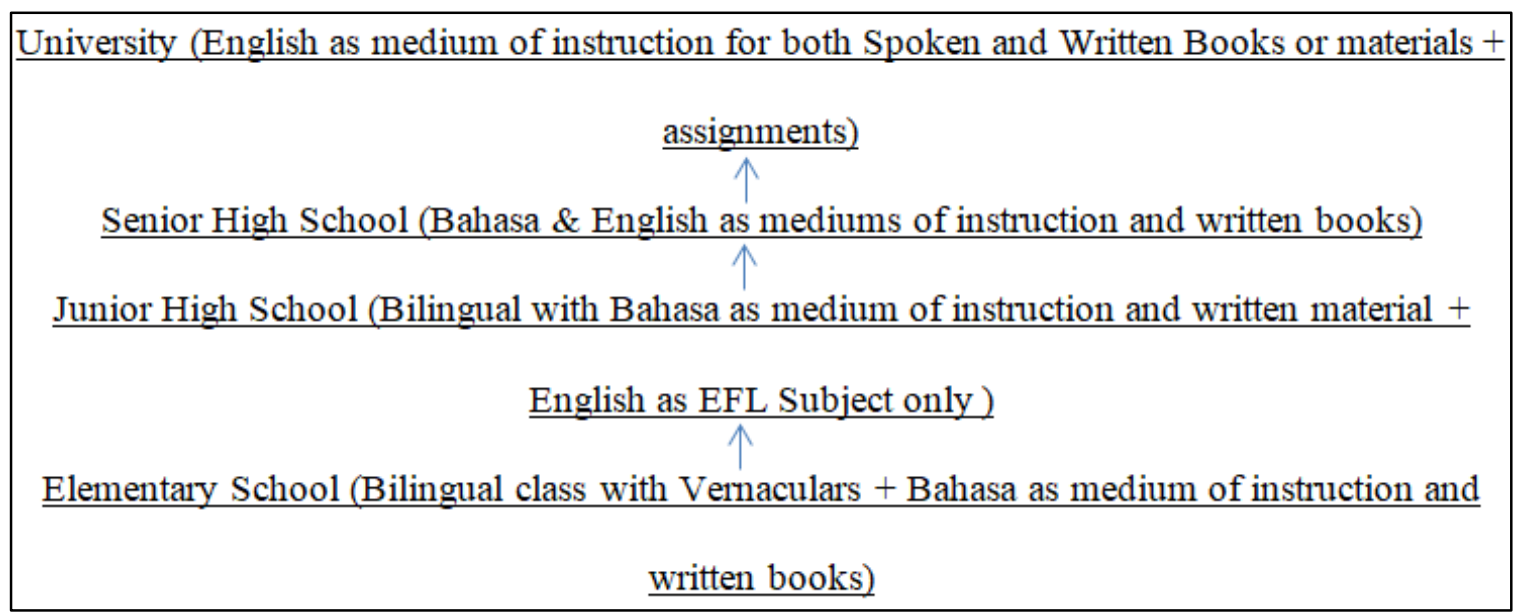

(Schema 2: The proposed model for language education policy in Indonesia)

Once they enter Junior High School, the medium of language instruction will only be given in the national language which is Bahasa. At this level, Bahasa is used to mainly facilitate the teaching and learning process. The students will be introduced to English but only as a subject of English as Foreign Language Lesson or English is only used as a medium of instruction when the students are studying English subjects in the class. Once the class if over, they can freely speak either in Bahasa or in English. This time is the phase where the students can get used to using English practically but not as compulsory.

In the Senior High School level, the situation is similar to the junior high school. However, the portion of English is increased. The students will be given the language of instruction and written materials bilingually which are Bahasa and English. This will be applied to all subject lessons in the school. So, at this level, there has been an additional time for the students to speak in English which is not only when they are studying English in the class but also whey they are studying other subjects. When they encounter difficulties they can resort back to their Bahasa that they have studied since elementary school. 
Once completing their high school, they will continue their study to the university level which is either to State or to private university. Here, English will be one of the compulsory subjects along with each student respective program. At this level, the students are expected to be able to communicate in English either in spoken or in written form. The medium of Instruction and books or materials will entirely be served in English. All assignments whether they are course works, quizzes, or exams will be in the form of English.

University level is the most different one where English will be the only language source that the students use. At this level, students are expected to engage in international community such as conducting research, doing publication, and even most of the learning materials are usually written in English. Once they graduate, they are expected to not only compete at the national level but also to the international level and English will be a very important skill to have.

Therefore, after the students graduate from university, they will be a person who can speak their vernaculars, official language (Bahasa), and International Language (English). However, some of them have different interests in a particular language than English, they may pursue it but the compulsory one is English. Government will still allow the school to have other language teacher than English such as French, Russian, Chinese, or etc.

\section{ARGUMENTS TO SUPPORT THE PROPOSED LANGUAGE POLICY}

\section{Rights and Equality}

Everyone should be treated equally before the state. Having equal rights and responsibilities are the indicators of the provision of state equal treatment (Robichaud \& De Schutter, 2012). This principle is not limited to the case of citizen obligation such as paying tax and getting public facilities only. Instead, the ability to express ideas using any chosen language should also be considered as a part of rights. In a special case such as the court system, when one can not express his/her ideas due to the different medium of communication, the government should provide alternative ways for special accommodation such as an interpreter (Annamalai, 2002). If that one does not have this help, he/she might not be able to appropriately express ideas. In other words, he or she has lost the freedom of speech (Arzoz, 2010) and fair trial treatment which is commonly known as the basic rights in democratical countries.

On the other side, Banda (2000) claims, in some cases the reason why some languages are excluded in a particular situation such as education area is because of its degree of suitability not because of discrimination. For example, many vernacular languages do not have orthography systems. As the consequence of bringing vernaculars in the education systems can 
be a new problem for the education itself. However, the provision of vernacular languages in the education sector does not necessary means it has to be accommodated exactly as the same as other languages (Liddicoat \& Taylor-Leech, 2015). Vernaculars can be set as the language of instruction when they do not have writing systems. The point is that this can help some students or people who are not capable enough of the majority language. This can be a serious problem for them as they will not be able to convey and follow the process of teaching and learning in the class. Some information which is an important part of the lesson explanation might not be understood. As a consequence, the students might fail to understand a complete knowledge of knowledge due to the language barrier. Thus, the vernacular language can gain a similar position as the other applied languages so that they can be acknowledged.

Furthermore, recognition of language freedom is, of course, necessary for the acknowledgment of language subjects. Robichaud \& De Schutter ( 2012) claim that "people's self-respect and dignity are often affected by the esteem their language gets from others or the state" (p. 136). The fact that minority groups with minority languages feel inferior seems to be undeniable. It is generally triggered by the social paradigm that minority groups are associated with poverty, lack of education, and crime. As a result, often parents from the minority groups do not even want to inherit their language to their children ( see Kullick, 1997). This feeling of inferiority needs to be exterminated first. Paulston (1997) argues that by highlighting the linguistic right of the minority, it is pulling them up into existence. When the linguistic rights of those who have been put arbitrarily in the unfortunate position as the minority are invoked, they might get better attention and recognition about their existence. Therefore, by providing a proper space for the vernaculars in educational settings together with official language (Bahasa) as well as the international one which is English, the government does not only provide their citizen with equal rights but also drives the society into more open-minded perspective.

However, it is also necessary to precondition the teacher at the very beginning when applying vernacular or minority language in the classroom as a policy (Tupas, 2015). If the teachers in charge do not have the vernacular speaking skill, they will not be able to make the language be spoken in the class. As a consequence, they may just teach in the class but without applying the policy altogether. Therefore, preparing the teachers first before sending them to the practical reality will be one of the best solutions to pursue.

\section{L1 Assistance In Early To Both Study And Acquire New Languages}

Providing the students who are not yet mastering the target language (national or English) may help them to get significant achievements. When teachers assist their language learners who are limited in the skill of the target language, learners can still effectively get 
engaged with the classroom activities (Cincotta-Segi, 2011). It means that the students can still actively follow the content of the lesson despite limited access to the target language that is used as the classroom instruction. Furthermore, when the students are given access to their L1 and L2, they can activate their background knowledge that they may have already had to process more the new information. Tavares (2005) argues that in the case of a science classroom, learners may deepen their understanding of a concept when they are assisted with L1 and L2. In fact, through the study conducted by Thomas and Collier (2002), who conducted a study by analyzing students' records from each of the five school districts throughout the United States found out that there is a significant improvement of long term academic achievements of the students from minority language when they are accommodated with the L1 instruction within their classroom. Therefore, providing sometimes when the bilingual students' academic achievement is low, it is due to their condition who are not yet mastering the language of instruction not because they are academically not qualified in that classroom.

When the learners learn a subject in a language classroom, they may be better equipped with L1 for acquiring the target language. Robichaud \& De Schutter (2012) claim that when we want to express our idea in another language we need to be able to express it in our language first. Our first language has all the possible vocabulary to arrange the information we need before being sent to and processed by our brain as our brain is not having control for the target language and still in the transition process. Auerbach (1993) argues that early English Second Language learners need L1 for the transition stage to the target language. It is due to the fact that moving from L1 to L2 might not be easy for early learners. One of the common problems is that the limitation of vocabulary mastery. This situation can be very stressful for the learners; get stuck in that situation and not able to convey the lesson. However, L1 service can reduce this cognitive overload and decrease the learner's anxiety (Schweers, 1999; Bruen \& Kelly, 2014). Therefore, the classroom environment will be more relax and enjoyable (ibid). However, Krashen (1998) argues that allowing the use of L1 in L2 language learning can actually give negative effect because it limits the students' exposure of using the target language as the comprehensible input. Yet, if the learners are unable to make use of the input as the result of their language limitation then the input will not be advantageous for them.

Also, the Bilingual classroom teaching can also be beneficial for students from other aspects. Hornberger \& Vaish (2009) claims that, when the students learn in the bilingual classroom, they do not only improve their target language knowledge but also their local language. It is difficult to neglect this idea as previously mentioned that L1 has a considerable function for the target language acquisition. Furthermore, bilingual students have two resources which are the L1 and L2. They have enough experience to learn another language. This idea is 
derived from Kang's (2012) claim that bilingual children have better phonologic awareness. They have more knowledge about language sound as the result of learning the either L1 or L2 with different phonology. Therefore, they have pre-resources to acquire another language that might different language sounds from their first language in pronunciation but quite similar to the L2 that they have learned in the classroom.

Therefore, the proposed language policy in this paper always provides a transition phase for the students to get engage with the new language while relying on the language that they have mastered. For example, at the elementary level, Bahasa is introduced to them in the form of instruction and written book materials while relying on vernacular when there is a language barrier in communication. Their teachers are bilinguals using both Bahasa and vernacular. This situation is quite similar to the junior high school level. The students are introduced to English but in a limited setting (classroom only). Most of the time, they will rely on Bahasa that they have mastered during elementary school. After that, in the senior high school, they began to master the English as all subjects are taught in Bahasa and English. After graduating and entering university, they will have to start engaging in a wider environment internationally. English will be very important at this level.

\section{Conflict Preventions}

Mismanagement on language policy might cause a fatal result for the continuity of a state. People and language are two inseparable entities. They are like two sides of a coin which are inexorably connected. The coin will not have economic value if one side is absent. This principle might also be applied to language and people. Robichaud \& De Schutter (2012) argue that there is a strong attachment between a person and a language he or she has because language constitutes someone's inherent identity. Simply, when someone is physically identified as Chinese the assumption will always fall to the deduction that she or he can speak Chinese and. Then, the strong relationship between a person and his or her language will turn out to be a negative reaction when he or she is separated from the language (Bloommaert \& Verschueren, 1998). The most common negative reaction is the emergence of separatist movement by the groups who feel oppressed by what they define as unfair language policy.

Several examples where separatism occurs as the result of language policy are enough to signal that language is of course very important. First, the separation of the oppression that was done by the former Soviet Union from its regions in which using Russian as the only legitimate language. It was the instigator of separatist movements that they claim fought for freedom (Bloommaert \& Verschueren, 1998). As a result, some former Soviet Union territories declared their independence and became a separate country from Russia. In a similar vein, (Boomgaard, 2008) argues that language policy that does not recognize even tend to oppress 
minority is the major cause of the separatist movement of Bretonite. This happens because many of French policies at that moment did not in line with the bretonite culture including language. In addition, Tamil Tiger separatism movements in Sri Lanka were born as a disappointed feeling upon the country's treatment to favor the majority language Sinhala over the minority language (Kearney, 1978). Therefore, to carefully manage the language policy is necessary to prevent the disappointment of groups of minorities.

Meanwhile, for the Indonesian context, dealing with language policy in which can accommodate public interest is really vital. Having been very diverse with culture and ethnicity, at least there are 719 individual languages used actively by speakers who can be enlisted in this country (Gordon, 2014). Separatism is not a new thing such as in the Aceh region (See Chalk, 2001) and East Timor (see Strating, 2014). Although, the major cases happened with the two cases were not mainly language issues; what can be learned is that Indonesia is very prone to the cause of separatism. Accommodating the minority with recognition of their language will be one of the positive acts to prevent the conflict from appearing.

Furthermore, appropriate language policy management can also bring benefits to the economic sectors. Robichaud \& De Schutter (2012) argue that sometimes if society does not have a similar language it can slow down the economic sectors. Economic activity relies much on communication and understanding therefore without similarly understandable language the communication can be hindered and slow down the economy.

In conclusion, by referring to what Ellingsen, (2000) argues that language might trigger a conflict, by managing a proper language policy for Indonesia can be understood as a way of purging one potential factor for conflicts and separatism. Once the conflict occurs the cost of benefits of maintaining a one-language policy will not be more beneficial than applying the multi-language policy. This can be covered through the policy proposed where vernaculars as minority languages are used and preserved along with Bahasa as the national or official language. If in the future, the students find it difficult to communicate using their vernacular language, they can easily shift to use Bahasa as the medium of communication.

\section{Securing Bahasa from Elementary and Senior High School National language for National Identity}

National language also plays an important role to preserve the sense of unity among diverse Indonesian society and provide national identity. Merkelbach (2009) states that "broadly shared language is very often a primary and critical component in the successful molding of a population as a nation" (p. 1). The fact that Indonesia is very diverse especially in term of language, it is important to have a language that can be shared broadly among others 
which is known as the national language. It can be a facilitator to construct and express collective identity (Tinsley, 2015) as Indonesian. This collective identity can be understood as an artificial identity that can act as a glue to protect Indonesian people from any possibility of ethnic tension and conflict. Despite having a single national language, López C (2014), using Malaysia's case, argues that national unity will be achieved by honoring the uniqueness of a diverse society. He explains that the national identity as a Malaysian people is constructed from accommodating the three major ethnic languages which are Malay, Chinese, and India.

However, the key to making the policy works well is related strongly to the idea of commitment. In creating a policy that honor diversity, it is imperative for the government to put their highest commitment to it so that the expected result will come. Otherwise, the language policy will lead to failure. It also happens in the case of Malaysia. Although the language policy was run well at first but practically, it does not work well. In fact, Malaysia does not treat the Chinese and Tamil language similarly as the official language of Malaysia is solely Malay and not the other two (see Stephen, 2013). Therefore, border and separation sometimes can still be felt among Malaysian people who Chinese, India and Malay ethnicity.

\section{Rationalization English Only in Higher Education}

\section{English for Globalization}

The education of International lingua franca can contribute to economic growth. The skill of communication is commonly known to be one of the key determinations in seeking a good job or creating business. Robichaud and De Schutter (2012) explain that language is human capital as communication is an important aspect in the job field. Workers candidate who speaks English is considered to have more points rather than those who can only speak one language. Because, when the workers are employed in economic sectors where goods and services are exchanged across national boundaries, different language can be a barrier (ibid). This problem can be solved if each economic doer can communicate using lingua franca such as English (Ibid).

Indonesia has given its agreement to be a member of the ASEAN Economic Community (Heilmann, 2015). It means that all ASEAN countries have agreed to make the economic transaction among them easier than before. Free trade, low goods tax, and free limited visa would be the three among the consequences of this agreement. This program is more or less like the European Union. Since each member has a different language, then it would be difficult for them to communicate. All ASEAN member countries have English as a foreign language for their students to learn. It will likely to see people interact with English when they interact with other people from ASEAN countries. Therefore, then it will be easier for each members ' people to interact with one another. 


\section{CONCLUSION}

Finally, there are two points that I would like to conclude through this paper. The first one, it is imperative to have a language policy that can promote unity and prevent any potential separatism, provide a sense of belonging to the nations and ethnic culture in terms of nationalism, and open access to knowledge enhancement and the global world. Secondly, it is also important to have qualified and committing teachers to the implementation of language policy. If both points are present, the benefits of language policy can obviously be obtained.

\section{REFERENCES}

Ager, D. (2001) Motivation in Language Planning and Language Policy. Clevedon: Multilingual Matters Ltd.

Akiba, M., LeTendre, G. K., \& Scribner, J. P. (2007). Teacher quality, opportunity gap, and national achievement in 46 countries. Educational Researcher, 36(7), 369-387.

Al Qurtuby, S. (2015). Interethnic Violence, Separatism and Political Reconciliation in Turkey and Indonesia. India Quarterly: A Journal of International Affairs, 71(2), 126-145.

Annamalai, E. (2002). Language policy for multilingualism. Actes du Congrès mondial sur les politiques linguistiques.

Arzoz, X. (2010). Accommodating linguistic difference: Five normative models of language rights. European constitutional law review, 6(01), 102-122.

Auerbach, E. R. (1993). Reexamining English only in the ESL classroom. Tesol Quarterly, 27(1), 9-32.

Banda, F. (2000). The dilemma of the mother tongue: Prospects for bilingual education in South Africa. Language culture and curriculum, 13(1), 51-66.

Blommaert, J., \& Verschueren, J. (1998). The role of language in European nationalist ideologies. Language ideologies: Practice and theory, 189-210.

Boomgaard, M. (2008). The rise of militant Bretonité. National Identities, 10(3), 281-293.

Bruen, J., \& Kelly, N. (2014). Using a shared L1 to reduce cognitive overload and anxiety levels in the L2 classroom. The Language Learning Journal, 1-14.

Chalk, P. (2001). Separatism and Southeast Asia: The Islamic Factor in Southern Thailand, Mindanao, and Aceh. Studies in conflict and terrorism, 24(4), 241-269.

Cincotta-Segi, A. R. (2011). Signalling L2 centrality, maintaining L1 dominance: teacher language choice in an ethnic minority primary classroom in the Lao PDR. Language and Education, 25(1), 19-31.

Commentary: Indonesia seeks to abolish national exams but could end up creating a new rat race. (2020, January 27). CNA. Retrieved from 
https://www.channelnewsasia.com/news/commentary/indonesia-education-nationalexam-pisa-nadiem-makarim-test-teach-12296096

Diknas, P. (2009). Tingkat Pencapaian Perkembangan Anak Taman Kanak-kanak.

Ellingsen, T. (2000). Colorful community or ethnic witches' brew? Multiethnicity and domestic conflict during and after the cold war. Journal of Conflict Resolution, 44(2), 228-249.

Gordon, Raymond G., Jr. (Ed.). (2014, September 01). Ethnologue: Languages of the World. Retrieved from http://www.ethnologue.com/.

Goss, J. D. (2000). Understanding the" Maluku Wars": Overview of Sources of Communal Conflict and Prospects for Peace.

Heilmann, D. (2015). After Indonesia's Ratification: The ASEAN Agreement on Transboundary Haze Pollution and its Effectiveness as a Regional Environmental Governance Tool. Journal of Current Southeast Asian Affairs, 34(3), 95-121.

Hendarti, L. (2012). Institutional Strengthening of Education for Sustainable Consumption (ESC).

Hornberger, N., \& Vaish, V. (2009). Multilingual language policy and school linguistic practice: globalization and English-language teaching in India, Singapore and South Africa. Compare, 39(3), 305-320.

Indonesia, R. (2002). Undang-Undang Dasar Negara Republik Indonesia Tahun 1945. Sekretariat Jenderal MPR RI.

Jaffe, A. (2011). Critical perspectives on language-in-education policy: The Corsican example. Ethnography and language policy, 205-229.

Kang, J. Y. (2012). Do bilingual children possess better phonological awareness? Investigation of Korean monolingual and Korean-English bilingual children. Reading and Writing, 25(2), 411-431.

Kearney, R. N. (1978). Language and the rise of Tamil separatism in Sri Lanka. Asian Survey, $18(5), 521-534$.

Kebudayaan, K. P. D. (2012). Dokumen Kurikulum 2013. Jakarta: Kemendikbud.

Kirkpatrick, A. (2007). World Englishes paperback with audio CD: Implications for international communication and English language teaching. Cambridge University Press.

Krashen, S. (1998). Comprehensible output?. System, 26(2), 175-182.

Kulick, D. (1997). Language shift and cultural reproduction: Socialization, self and syncretism in a Papua New Guinean village (No. 14). Cambridge University Press.

Liddicoat, A. J., \& Taylor-Leech, K. (2015). Multilingual education: the role of language ideologies and attitudes. Current Issues in Language Planning, 16(1-2), 1-7. 
Lopes, A. J. (1998). The language situation in Mozambique. Journal of Multilingual and Multicultural Development, 19(5), 440-486.

López C, C. (2014). Language is the Soul of the Nation: Language, Education, Identity, and National Unity in Malaysia. Journal of Language, Identity \& Education, 13(3), 217-223. MacDonald, S. B., \& Lemco, J. (2001). Indonesia: living dangerously. CURRENT HISTORYNEW YORK THEN PHILADELPHIA-, 100, 176-182.

Merkelbach, C. (2009). Language \& national identity in Asia. International Journal of Multilingualism, 6(3), 340-342.

Murniati, C. T., \& Riyandari, A. (2016). The Implication of Pre-service Teacher's Belief About Grammar Teaching and Learning for English Language Policy in Indonesia. The Implication of Pre-service Teacher's Belief About Grammar Teaching and Learning for English Language Policy in Indonesia, 16(1), 133-144.

Musgrave, S. (2014). Language shift and language maintenance in Indonesia. In Language, Education and Nation-building (pp. 87-105). Palgrave Macmillan, London.

Nababan, P. W. J.. (1991). Language in Education: The Case of Indonesia. International Review of Education / Internationale Zeitschrift Für Erziehungswissenschaft / Revue Internationale De L'education, 37(1), 115-131.

Nasional, D. P. (2007). Peraturan Mendiknas No 22 dan 23 Tahun 2006 Tentang Standar Isi dan Standar Kompetensi Lulusan Untuk Satuan Pendidikan Dasar SD.

Nasional, S. P. (2003). Undang-Undang Republik Indonesia Nomor 20 Tahun 2003. Tentang: Sistem Pendidikan Nasional, Jakarta, Depdiknas.

Paulston, C. B. (1997). Language policies and language rights. Annual Review of Anthropology, 73-85.

Robichaud, D., \& De Schutter, H. (2012). Language is just a tool! On the instrumentalist approach to language. (pp. 124-145). Cambridge Press.

Rubin, J., \& Jernudd, B. H. (1971). Can language be planned? Honolulu. University Press.(2000), Historical and theoretical perspectives in language policy and planning, Journal of Sociolinguistics, 4(2), 196-213.

Rüland, J., \& Manea, M. G. (2013). The Politics of Military Reform in Indonesia and Nigeria. In The Politics of Military Reform (pp. 3-25). Springer Berlin Heidelberg.

Schweers Jr, W. (1999, April). Using L1 in the L2 classroom. In English Teaching Forum (Vol. 37, No. 2, pp. 6-9).

Shohamy, E. G. (2006). Language policy: Hidden agendas and new approaches. Psychology Press.

Statistik, B. P. (2013). Data Statistik Indonesia. 
Stephen, J. (2013). English in Malaysia: a case of the past that never really went away?: English language learning in former British colonies-in this case, Malaysia-may still be influenced by the negative attitudes towards the stereotyped image English has in these countries. English Today, 29(2), 3-8.

Strating, R. (2014). Contested Self-determination: Indonesia and East Timor's Battle over Borders, International Law and Ethnic Identity. The Journal of Pacific History, 49(4), 469-494.

Sudaryanto, S., Soeparno, S., \& Ferawati, L. (2019). Politics of Language in Indonesia (19752015): Study of History and Language Policy. Aksis: Jurnal Pendidikan Bahasa dan Sastra Indonesia, 3(1), 129-139.

Tavares, N. J. (2015). How strategic use of L1 in an L2-medium mathematics classroom facilitates L2 interaction and comprehension. International Journal of Bilingual Education and Bilingualism, 18(3), 319-335.

Thomas, W. P., \& Collier, V. P. (2002). A national study of school effectiveness for language minority students' long-term academic achievement.

Tinsley, M. (2015). Proclaiming Independence: Language and National Identity in Sékou Touré's Guinea. Postcolonial Studies, 1-20.

Tupas, R. (2015). Inequalities of multilingualism: challenges to mother tongue-based multilingual education. Language and Education, 29(2), 112-124.

Webb-Gannon, C. (2014). Merdeka in West Papua: Peace, Justice and Political Independence. Anthropologica, 56(2), 353-367.

Weinstein, B. (1980) Language Planning in Francophone Africa. Language problems and language planning, 4, 55-77. 